\title{
An Analysis of Speech Act Used in London Has Fallen Movie
}

\author{
Zulfa Tutuarima ${ }^{1}$ \\ ${ }^{1}$ Universitas Muria Kudus \\ zulfaarima@gmail.com \\ Nuraeningsih ${ }^{2}$ \\ ${ }^{2}$ Universitas Muria Kudus \\ 2nuraeningsih@umk.ac.id \\ Rusiana $^{3}$ \\ ${ }^{3}$ Universitas Muria Kudus \\ ${ }^{3}$ rusiana@umk.ac.id
}

\begin{abstract}
The most significant thing in speech act is the message that the speaker wants to convey. It means when using language is produces not only a sentence but also perform an action. The aims of the research are (i) to find out the kinds of speech act used in London Has Fallen Movie (ii) to find out the way of speech act and the classifications of illocutionary act used in London Has Fallen Movie. This research uses descriptive qualitative research. This research figures out the kinds of speech act and the classifications of the illocutionary act used in London Has Fallen Movie. The result of the research shows that: (i) there are 76 utterances of speech act used in London Has Fallen Movie which is the most dominant is illocutionary act consist of 37 utterances. (ii) there are 99 utterances of the classifications of the illocutionary act, and the most dominant categories are directive with 32 utterances and expressive with 23 utterances.
\end{abstract}

\section{ARTICLE HISTORY}

Received 19 September 2018

Accepted24 October 2018

\section{KEYWORDS}

Pragmatic; speech act; the classification of illocutionary act

\section{Introduction}

Language is one of the essential things in human life. It is used to communicate with others in their daily life. Because it has an essential role so language cannot be separated from human life, either spoken or written. It takes significant things because they can extend what they want to say and also they can communicate what they want. Beside that language is also used to express their feeling, idea, and also thought.

Nowadays, using language for communication with each other is necessary, when the speaker and hearer understand what they are talking about. It makes the best result for communication. The communicative act or called as the utterances of the speaker commonly represent verbal communication. It means that people 
do not only produce an utterance which is focused on grammatical structure and every word but also the way they perform the utterance.

Pragmatics is a branch of linguistics which is a study about how context contributes to the meaning. Pragmatics consists of speech act, deixis, conversational implicature, cooperative principles, and politeness principles. Pragmatics itself explains how using language in context, and the way in people produce and understanding the meanings through language. In other words, pragmatics tells about people's intended meanings, their assumptions, their purposes or goals, and the kinds of actions.

Speech acts are the study of intended meaning the utterances spoken and written. Moreover, the most significant things in speech act are the message of the speaker intention, so the hearer understands a message from the speaker. Speech act is divided into three parts; those are a locutionary act, illocutionary act, and perlocutionary act. Speech act is the utterance which the speaker says, or the speaker performs in every speech. The study of speech act is significant for everyone. The importance of studying speech act is to make comprehend what message that discovered in every utterance.

The students of English Education Department should be able to know the speech act used and how to use it when they are talking to the other. If they communicate without using speech act, there will be a misunderstanding between the speaker and hearer. Using the speech act is very important especially in communication because it is an act of communication, a speech act success if the audience identifies, by the speaker's intention, and the attitude being expressed.

Usually, speech acts can be found in conversation. The conversation in the movie can be an excellent example of speech acts because it represents the complicated case of speech acts in order to find out what the main character does by saying something. The one of important that mostly occurred in the movie is the dialogue among the characters.

Here the writer wants to analyze speech act that is used in the movie, and the title is London Has Fallen. This movie is political, action, thriller which played by the famous US actor Gerard Butler and Aaron Eckhart directed by Babak Najafi and the duration is about 99 minutes, although have a long duration but it can't make bored this movie serves strain atmosphere, curiosity, and amazed with the beauty of London city which is fall out by terrorists.

\section{Statement of the Problem}

Based on the background of the research above, the writer formulates the statement of the research below:

a) What is the speech acts used in London Has Fallen Movie?

b) What are the classifications of illocutionary act used in London Has Fallen Movie? 


\section{Theoretical Framework}

Pragmatics is concerned with the study of meanings as communicated by a speaker (or writer) and interpreted by a listener (or reader). It means that more to do with the analysis of what people mean by their utterances that what the words or phrases it those utterances might mean by themselves. Pragmatics is the study of speaker meaning stated by Yule (1996).

Speech act is a concern with the speaker's communicative intention in producing an utterance, and it is defined by the purpose for which the speakers use the language, for example, to make a request, to apologize, and to report stated Yule (1996). It means that the speech act is always used in daily life when speakers say something and hearer know the purpose of speakers' says in the communication so it will make the best result in the communication.

While using the language people do not produce only an isolated series of sentences, but also perform an action. In other words, by using the language, they either do something or make others do something such as thanking, requesting, promising, and so on argued by Marquez Reiter (2000).

According to Austin (1969) is acknowledged as the creator of Speech Act Theory. Based on comparison between constative utterances and performative utterances, Austin refers to "constative utterances" to those utterances which are used to describe or constate something, and those which thus are true or false, and "performative utterances" to those utterances not only perform a speech act beyond the assertion but also at the same time describe the speech act. Austin divided three parts of Speech Act that are Locutionary Act, Illocutionary Act, and Perlocutionary Act.

1. Locutionary Act

Locutionary acts are the act that is performed in order to communicate, the act of actual uttering (the particular sense and reference of an utterance) the study is the domain of field like phonetic, phonology, and linguistic semantics. Alternatively, in other words, a locutionary act is the basic act of utterance or producing a meaningful linguistic expression.

2. Illocutionary Act

Illocutionary act is an act performed in saying something, making statement or promise, thanking, asking a question, etc. Alternatively, an illocutionary act is performed via the communicative force of an utterance such as making a statement, offer, explanation, or for some other communicative purpose.

3. Perlocutionary Act

A perlocutionary act is an act performed by saying something in a particular context. It represents the change achieved each time, in a particular context. These acts are the by-products of acts of communication; 
acts performed using saying something, moving someone to anger, consoling someone in his distress, etc. It means to create an utterance with a function without intending it to affect.

Searle (1975) argued that the speech act is defined as an action changing the universe of discourse when a speaker utters it, and a recipient grasps it. It may be oral as well as written, or even expressed via some other communication from such as sign language. Searle divides five categories for Illocutionary Act that is:

1. Assertive (Representative)

The purpose is to convey information about some states of affairs of the world from the speaker to the hearer, such as boast, assert, claim, characterize, state, diagnose, class, complain, and conclude.

2. Directives

Where the speaker requests the hearer to carry out some action or to bring about some states of affair such as order, command, insist, suggest, request, ask, beg, plead, pray, entreat, permit, and advise.

3. Commissive

The purpose is to show that the speaker undertakes to do something by expressing an intention such as promise, pledge, threaten, or any other words that match the criteria of commissive.

4. Expressive

The purpose is where speaker brings about some state of affairs by the more performance of the speech act or reveal the speaker's state of mind about a situation such as apologies, welcome, thanks, congratulate, console, or other words that match with expressive.

5. Declaratives

The purpose is where the speakers bring about some state of affairs by the more performance of the speech act or aim to create a change such as resign, appoint, declare, name, call, define, nominate, etc.

London has fallen is the one of famous movie was released on 1 March 2016 and directed by Babak Najafi the one of great director in the US and has directed so many famous movies such as London has fallen (2016), Easy money II: Hard to kill (2012), Boys (2015), and the newest movie is Proud Mary which is released on 2018. This is action thriller movie and starring the greatest actors and actresses, for the main actor is Gerard Butler as Mike Banning and Aaron Eckhart as President Benjamin Asher. This movie is a sequel from the previous movie that is Olympus has fallen was released in 2013. 


\section{Method Of The Research}

a) Research Design

The research design of this study was qualitative research. Arikunto (2010) stated that qualitative research was conducted to describe the current status of a phenomenon that while exist at the time of the study. One of the characteristics of this research is there is no control of treatment as it was around in experimental research.

b) Data Collecting

The method of collecting data was some ways which could be used to collect the data. In collecting the data, the researcher tookthe following step:

1. Watching London Has Fallen Movie in order to understand the utterances.

2. Searching the English subtitle from internet copied from https://opensubtitles.co/download-subtitle/London-Has-Fallen$\underline{2016 \_73569}$

3. Making the transcription based on the subtitle.

c) Data Analysis

The researcher chose a content analysis to analyze the data. The material may be public records, textbooks, letters, films, diaries, themes, reports, or another document. The steps in analyzing the data were:

1. Identifying the speech act and categories of Illocutionary act that found in the movie.

2. Analyzing the data into more specific speech act and categories of Illocutionary act.

3. Interpreting the results of the speech act and classifications of Illocutionary act which are used in London Has Fallen Movie.

4. Concluding the results of the speech act and the classifications which used in the London Has Fallen Movie

\section{Result and Discussion}

The researcher analyzes the speech act used in London Has Fallen Movie based on the conversation is used in the movie. It is directed by Babak Najafi while for the script is written by Creighton Rothenberger and Katrin Benedikt, the duration of this movie is 99 minutes, and the writer found the dominant of speech act are used in this movie. So in this movie, there are so many utterances or conversations are considered as a speech act. For locutionary act which used in this movie is 14 utterances, an illocutionary act is 37 utterances, and perlocutionary act is 25 utterances. 
For the classifications of the illocutionary act which is used in this movie is 99 utterances. While the categories which dominant this movie is directive which utterance found is 32, and other categories are found in this movie are assertive is 26 utterances, expressive is 23 utterances, commisive is 12 utterances, and declarative is six utterances.

Locutionary act used in the movie is 14 utterances and fortunately in this movie locutionary act is still appearing because the entire locutionary act is not used in many movies. Here is an example of a locutionary act which is used in the movie.

\section{Locutionary Act}

Raza: Did Philippine Intelligence track you? (speaker)

Kamran : (He listen and doesn't replay what Raza's said.) (hearer)

Based on the example above, it proves that the utterance or conversation which belongs to locutionary act is just real message from the speaker and the hearer did not give the reaction what are the speaker's said. All of the utterances which belong to the locutionary act in this movie were having the same condition; when the speakers were saying something, then the hearer was just stayed and listen to them. From the example above, when Raza (speaker) said: "Did Philippine intelligence track you?" Kamran (hearer) was passing through the speaker without giving the reaction, and there was no intention from the hearer to replay what the speaker said.

\section{Illocutionary Act}

Trumbull: How bad is it? (speaker)

Staff: It is pretty goddamn bad, sir. All lines of communication have been compromised, both civilian and military. (hearer)

In the examples above the speaker is trying to convey what they are wanted or what they wanted to say. The speaker tries to explain. When Trumbull (speaker) said How bad is it? When Trumbull as the first speaker is want to hear the explanation from the other staff (hearer), and then he is explaining Trumbull (speaker) and said "it is pretty goddamn bad, sir. All lines of communication have been compromised, both civilian and military". When the staff (hearer) is saying like the utterances above it means that the hearer wants to give the response based on what the other speaker said.

\section{Perlocutionary Act}

Staff: Sir, I got your son on video chat. (speaker)

President Asher: Excellent. He had his first date last night. (hearer) 
When the speaker is saying something, then the hearer directly moves and do what the speaker's want. When staff(speaker) said "sir, I got your son on the video chat," and president(hearer) is giving a reaction "excellent, he had his first date last night," here the hearer is giving a happy reaction, and the speaker is receiving a good response from the speaker.

In this movie, so many utterances are categorized to the classification of illocutionary act. Here is the example and the description of the classification of illocutionary act is used in this movie.

\section{Assertive}

President Asher: What are you guys so damn nervous about? (speaker) Lynn: British are world class, we all know their reputation. However, these are the trips I hate. Last minute out of the country no time to plan. (hearer)

The utterance above reveals as a claim because when the speaker (President Asher) said "What are you guys so damn nervous about? Then the hearer (Lynn) said "British are world class, we all know their reputation. However, these are the trips I hate. Last minute out of the country no time to plan." It can be explained that when the speaker (President Asher) is asking about the condition of the hearer, and the hearer (Lynn) states that British as a big and classy country, she is not ready for going to London and the hearers are agreed with her statement.

\section{Directive}

Mike: Move! Go, go! (speaker)

Voight: You okay sir? Keep your head down. (speaker)

President Asher : (Directly enter the car and keep his head down.) (hearer).

As seen in the example above when the speaker (Mike) said "Move, go, go" it indicates as a giving command to the hearer, and the hearer is following what the speaker said. Moreover, for the second speaker (Voight) said "You okay sir? Keep your head down." Both of those utterances are giving the command to the hearer who is directly doing what the two speakers (Voight and Mike) said.

\section{Commissive}

Lyyn: Mike? (speaker)

Mike: I always do, Sir. (hearer)

Based on the examples above, it can be seen that when the speaker (Lyyn) is asking to the hearer for making sure that the hearer (Mike) can handle it, then hearer (Mike) said "I always do sir," the hearer is showing his intention and promise he will do what the speaker wants.

\section{Expressive}


Jax: What a pleasure this is, handsome men visiting me on such a lovely evening. (speaker)

Mike: Long time, Jax. (hearer)

The example of expressive above is welcomed. It can be seen from the example above when Jax (speaker) said "What a pleasure this is, handsome men visiting me on such a lovely morning. The utterance above is considered as welcoming someone.

\section{Declarative}

word Mr. President? (speaker)

President Asher: I do solemnly swear that will faithfully execute the office of the President of the US. (hearer)

Based on the conversations above, the category of declarative which uses is declared. It can be seen when Kamran (speaker) said Okay. Say hello to the world Mr. President, any last word Mr. President? Then President Asher (hearer) states "I do solemnly swear that will faithfully execute the office of the President of the US, the utterance above is included in declarativebecause the speaker is declaring about the president that sincerely that he is never losing though he will die.

\section{Conclusion and Suggestion}

\section{Conclusion}

In this action thriller movie was released on March 1, 2016, and directed by Babak Najafi, there are 76 utterances found in this movie, which is the result for kinds of speech act. Illocutionary act is 37 utterances, the perlocutionary act is 25 utterances, and locutionary act is 14 utterances.Speech act which is dominantly used in this movie is an illocutionary act.

There are 99 utterances found in this movie, which is the result of the classifications of the illocutionary act. The directive is 32 utterances, assertive is 26 utterances,expressive is 23 utterances,commisive is 12 utterances, and declarative is six utterances. The classification of the illocutionary act which is dominant in this movie is directive with 32 utterances because this movie is an action thriller movie which is most of the utterances are giving an order to someone for doing something.

\section{Suggestion}

Hopefully, the readers will get knowledge that English is used especially in linguistics which becomes an important part in English. For the next researcher who wants to conduct similar research as I did before about linguistic, especially in the speech act, it can help them in their research. Moreover, this research is expected to be the references for those who are interested in the speech act. This research is still lack in some theory, so you can explore more sources to develop your research. 


\section{References}

Akinwotu, Samuel Alaba. 2013. A Speech Act Analysis of the Acceptance of Nomination Speeches of Chief Obafemi Awolowo and Chief M.K.O Abiola. English Linguistic Research, 2 (1), 43-51.

Akram, M. 2008. Speech Acts: A Constructive Study of Speech Acts in Urdu and English. Asian EFL Journal, 10 (4), 148-172.

Altikiri, SaharFarouq. 2011. Speech Act Analysis to Short Stories. Journal of Language Teaching and Research, 2 (06) 1374-1384.

Austin, J. L. 1962. How to do things with words. Cambridge: Harvard University Press.

Arikunto, Suharsimi. 2010. ProsedurPenelitian: SuatuPendekatanPraktek. Jakarta: RinekaCipta.

Bayat, N. 2013.A Study on the Use of Speech Act.Procedia Social and Behavioral Sciences, 70 (2013), 213-221.

DwiIsnawati, Fifin, SyamsulAnam, Sabta Diana. Speech Act Analysis of The Main Character in Shrek Movie Script. PublikaBudaya. 1 (3), 60-64.

Dylgjeri, A. 2017.Analysis of Speech Acts in Political Speeches.European Journal of Social Science Studies. 2 (2), 19-26.

Ghourchian, Marjan. 2012. Speech Acts in Drama Translation. Asian EFL Journal. 60 (2), 70-84.

Handayani, Jati. 2012. The Study of Speech Act in "Body of Lies" The Movie.Skripsi.Salatiga: STAIN Salatiga.

Hashiuchi, Sachiko, Taeko Oku. 2005. Main Approaches to Pragmatics. Chugokugakuen Journal. Vol. 4, 11-16.

https://opensubtitles.co/download-subtitle/London-Has-Fallen-2016 73569accessed on March 15, 2018.

Kaburise, P. 2012. Recognizing Speech Acts.Per Linguam, 28 (1), 36-48. 
Khalifah, Amalia. 2013. Analysis of Complaint Speech Act in The Help Movie by Tate Taylor.Skripsi. Surakarta: UniversitasMuhammadiyah Surakarta.

Kohandani, Mohammadreza, Nima Farzaneh, Mahmood Kazemi. 2014. A Critical Analysis of Speech Acts and Language Functions in Top Notch Series. Procedia Social and Behavioral Sciences.98 (2014), 1009-1015.

Levinson, Stephen C. 1983. Pragmatics. Cambridge, England: Cambridge University Press.

Morris, Charles W. 1988. Foundations of the Theory of Signs. Chicago: The University of Chicago Press.

Muttaqin, Usep. 2013. A Speech Act Analysis of Zaid's Utterances in Moustapha Akkad's Movie The Message. Skripsi. Yogyakarta: UIN SunanKalijaga Yogyakarta.

Nurhasana, Latifah. 2017. A Speech Act Analysis of Utterances in the Disney Animation Movie Script "Inside Out" by Pete Docter and Ronnie Del Carmen.Skripsi. Cirebon: IAIN Syekh Nurjati Cirebon.

Rahardi, Kunjana. 2005. Pragmatik. Kesantunan Imperatif Bahasa Indonesia. Jakarta: Erlangga.

Rumaria, Choerunnisa. 2015. An Analysis of Speech Acts in The Dead Poets Society. Skripsi.Yogyakarta: UniversitasNegeri Yogyakarta.

Searle, John R. 1975. Expression and Meaning: Studies in Theory of Speech Acts. London: Cambridge University Press.

Yule, G. 1996. Pragmatics. Oxford: Oxford University Press.

Zumaroh, Siti. 2012. The Analysis of Speech Act Used in "Air Force One” Movie Script.Skripsi. Salatiga: STAIN Salatiga. 